\title{
AKTIVITAS ANTIBAKTERI DARI FRAKSI DAUN BANDOTAN (Ageratum conyzoides L.) SECARA KROMATOGRAFI LAPIS TIPIS BIOAUTOGRAFI
}

\author{
Islamudin Ahmad \\ Laboratorium Penelitian dan Pengembangan FARMAKA TROPIS Fakultas Farmasi \\ Universitas Mulawarman, Samarinda, Kalimantan Timur \\ email: islamudinahmad@farmasi.unmul.ac.id
}

\begin{abstract}
Screening Ageratum conyzoides L. fraction for antibacterial activity using thin layer chromatography bioautography have been done. The method is based on thin-layer chromatography-direct bioautography of Ageratum conyzoides chloroform fraction. The aim of study to determine the antibacterial activity of chloroform Ageratum conyzoides $L$. fraction in TLC bioautography. Extraction was done by maceration using methanol solvent, followed by partition using chloroform solvent using liquid-liquid extraction method is done by chromatographic profile of each eluent comparison is then performed further fractionated using vacuum liquid chromatography method. Screening activity of the compound was done qualitatively raction results are antibacterial activity test using thin layer chromatography bioautography The results showed that the eluent to separate the components of a compound based on the chomatography profile is eluent n-hexane: ethyl acetate (2: 1), the results obtained by fractionation of the active fraction (51-53) Rf value of 0.59. Results of screening activity held chloroform fraction Ageratum conyzoides leaves are antibacterial activity which can be seen from the formation of inhibition zones in the region stain spot on the TLC plate were grown in glucose medium Nutrient. The results were analyzed descriptively, that is to describe the characteristics of the research which is obtained.
\end{abstract}

Keywords: TLC bioauttography, Ageratum conyzoides L., TLC profiles, antibacterial

\begin{abstract}
ABSTRAK
Telah dilakukan penelitian dengan judul skrining aktivitas dari fraksi daun bandotan (Ageratum conyzoides L.) secara kromatografi lapis tipis bioautografi. Penelitian ini bertujuan untuk mengetahui aktivitas antibakteri fraksi kloroform daun bandotan secara KLT bioautografi. Ekstraksi dilakukan secara maserasi dengan menggunakan pelarut metanol yang dilanjutkan dengan partisi menggunakan pelarut kloroform dengan menggunakan metode ekstraksi cair-cair yang dilakukan dengan melihat profil kromatografi dari setiap perbandingan eluen selanjutnya dilakukan fraksinasi lebih lanjut dengan menggunakan metode kromatografi cair vakum. Skrining aktivitas senyawa hasil hasil fraksi dilakukan secara kualitatif yaitu uji aktivitas antibakteri menggunakan metode kromatografi lapis tipis (KLT) Bioautografi. Hasil penelitian menunjukkan bahwa eluen yang dapat memisahkan komponen senyawa dengan baik berdasarkan profil kromatografinya adalah eluen n-heksana : etil asetat $(2: 1)$, hasil fraksinasi diperoleh fraksi aktif pada (vial fraksi 51-53) nilai Rf sebesar 0,59. Hasil skrining aktivitas yang dimiliki fraksi kloroform daun bandotan yaitu aktivitas antibakteriyang dapat dilihat dari terbentuknya zona hambat pada daerah spot noda pada plat KLT yang ditanam di dalam
\end{abstract}


medium Glukosa Nutrient Agar. Hasil penelitian yang diperoleh dianalisis secara deskriptif, yaitu dengan menjabarkan karakteristik hasil penelitian yang diperoleh.

Kata Kunci: KLT bioautografi, Ageratum conyzoides L., profil klt, antibakteri

\section{PENDAHULUAN}

Tumbuh-tumbuhan sejak lama telah dimanfaatkan oleh masyarakat sebagai bahan obat-obatan tradisional baik itu secara langsung maupun melalui pengolahan secara sederhana yang berupa jamu-jamuan (Darwis, 2000).

Sesuai dengan perkembangan ilmu pengetahuan dan teknologi khusunya dibidang kimia dan farmasi telah mendorong para peneliti untuk menggali potensi hutan Indonesia. Upaya ini penting mengingat semakin banyak jenis-jenis tumbuhan yang punah akibat eksploitasi hutan untuk industri. Disamping itu, penelitian bermanfaat untuk mencari alternatif dalam hal pengadaan bahan baku obat, validasi tumbuhan obat tradisional dan mencari senyawa baru yang dapat dimanfaatkan sebagai obat (Efdi, 1999).

Senyawa obat dapat diproduksi dengan berbagai cara, salah satunya yaitu dengan cara isolasi langsung dari bahan alam. Bandotan (Ageratum conyzoides L.) merupakan tumbuhan liar dan lebih dikenal sebagai tumbuhan pengganggu (gulma) di kebun dan ladang. Tumbuhan ini merupakan salah satu tumbuhan yang diketahui secara empiris mempunyai khasiat sebagai bahan obat. Bandotan digunakan sebagai obat radang telinga, radang tenggorokan, rematik, keseleo, pendarahan rahim, sariawan, tumor rahim, malaria, perut kembung, mulas, muntah, diare dan perawatan rambut (Dalimartha, 2007). Penelitian lebih lanjut untuk mengetahui keberadaan dan aktivitas senyawa aktif di dalam tumbuhan bandotan perlu dilakukan, sehingga pemanfaatannya sebagai obat menjadi lebih luas.

Sebelumnya telah dilakukan penelitian terhadap ekstrak dan fraksi nHeksana, etil asetat dan n-butanol daun bandotan, yaitu Aktivitas Antibakteri Daun Bandotan (Ageratum conyzoides L.) Terhadap Beberapa Jenis bakteri (Rasid, 2011). Identifikasi Metabolit Sekunder Dan Aktivitas Antioksidan Daun Bandotan (Ageratum conyzoides L.) (Simbolon, 2011) dan Bioaktivitas Terhadap Artemia salina L. Ekstrak Daun Bandotan (Arfianti, 2011), dari hasil penelitian tersebut diketahui bahwa daun bandotan memiliki aktivitas yang cukup baik dan memiliki kandungan metabolit sekunder yang cukup bervariasi (alkaloid, fenol, flavonoid).

Pada penelitian ini digunakan fraksi kloroform, diharapkan agar kloroform mampu menarik senyawasenyawa yang terkandung dalam sampel uji sekaligus dalam 1 (satu) fraksi (fraksi kloroform) selanjutnya dilakukan pengujian aktivitas antibakteri secara KLT bioautografi.

\section{METODE PENELITIAN}

\section{Ekstraksi sampel}

Sampel kering daun bandotan diekstraksi dengan menggunakan pelarut metanol. Proses ekstraksi dilakukan hingga diperoleh ekstrak metanol bersih (tidak tercampur residu / pengotor), pelarut ekstrak diuapkan dengan menggunakan rotary evaporator dengan tekanan rendah sehingga proses penguapan cairan penyari menjadi cepat hingga didapatkan ekstrak kental. Setelah itu ekstrak diuapkan kembali di water bath untuk mendapatkan ekstrak kasar daun bandotan. Ekstrak kasar kemudian disimpan dalam wadah tertutup rapat.

\section{Partisi Ekstrak}

Partisi dilakukan dengan metode ekstraksi cair-cair dimana ekstrak metanol daun bandotan ditimbang 
sebanyak $10 \mathrm{~g}$ kemudian dilarutkan dengan air sebanyak $100 \mathrm{~mL}$. Campuran air dan ekstrak dimasukkan ke dalam corong pisah, kemudian disiapkan pelarut kloroform sebanyak $100 \mathrm{~mL}$, dimasukkan tiap $25 \mathrm{~mL}$ kloroform ke dalam corong pisah. Setelah beberapa menit akan terbentuk 2 lapisan. Lapisan bawah (lapisan kloroform) ditampung dan diuapkan. Lapisan air dilanjutkkan ke fraksinasi selanjutnya dengan penambahan $25 \mathrm{~mL}$ kloroform (diulang hingga $100 \mathrm{~mL}$ kloroform). Hasil fraksinasi dikeringkan/diuapkan sehingga diperoleh fraksi kloroform kering.

\section{Fraksinasi secara Kromatografi Cair Vakum}

Proses selanjutnya adalah elusi dengan menggunakan kolom vakum. Dimasukkan fase diam (silika gel) ke dalam kolom hingga rata dan mampat. Selanjutnya serbuk sampel diletakan di atas permukaan fase diam, diletakkan kapas di atas permukaan serbuk sampel. Selanjutnya dielusi menggunakan eluen yang telah ditentukan, dimulai dari eluen dengan tingkat kepolaran rendah terlebih dahulu (n-heksana, 5:1, 4:1, 3:1, 2:1, 3:2, $1: 1$, etil asetat dan metanol). Proses elusi dibantu dengan penggunaan pompa vakum. Hasil elusi selanjutnya ditampung dalam wadah berbeda dari tiap eluen dan kemudian diuapkan (diperoleh 9 fraksi).

Masing-masing eluat yang telah ditampung dan diuapkan dilihat profil kromatografinya dengan menggunakan eluen $n$-heksana: etil asetat (2:1), hingga diketahui noda pada fraksi manakah yang memberikan pemisahan terbaik.

\section{Penentuan Profil Eluen KLT}

Untuk mengetahui jumlah komponen yang ada dalam ekstrak fraksi kloroform daun bandotan, dilakukan pemantauan dengan menggunakan kromatografi lapis tipis. Plat yang telah ditotolkan sampel dielusi dengan berbagai perbandingan eluen yang sesuai. Noda yang dihasilkan dilihat dibawah lampu UV dengan panjang gelombang 254 dan $366 \mathrm{~nm}$. Agar noda dapat terlihat lebih jelas maka plat kromatografi lapis tipis tersebut disemprot dengan pereaksi $\mathrm{H}_{2} \mathrm{SO}_{4} 10 \%$ dan kemudian dipanaskan di atas hot plate pada suhu $120^{\circ} \mathrm{C}$. Perlakuan tersebut di atas diulangi dengan menggunakan variasi eluen hingga didapatkan eluen tertentu yang mampu memisahkan senyawa dalam fraksi dengan baik.

\section{Uji Aktivitas Antibakteri secara Bioautogtafi}

Disiapkan fraksi uji yang telah dielusi. Dimasukkan 0,02 mL suspensi bakteri uji ke dalam cawan petri, kemudian dimasukkan medium GNA sebanyak $\pm 10 \mathrm{~mL}$ lalu diratakan dan dibiarkan memadat. Isolat yang telah dielusi pada plat KLT ditanam dalam medium GNA secara aseptis dan dibiarkan selama \pm 1 jam, setelah itu plat diangkat dari dalam medium, kemudian media uji diinkubasi dalam inkubator. Inkubasi dilakukan pada suhu $37^{\circ} \mathrm{C}$ selama 24 jam. Setelah diinkubasi selanjutnya diamati apakah terdapat zona hambat/zona bunuh yang terbentuk pada daerah noda (diamati dengan mensejajarkan noda pada plat dengan zona yang terbentuk dalam medium).

\section{HASIL DAN PEMBAHASAN}

\section{Ekstraksi dan Fraksinasi}

Proses ekstraksi dilakukan hingga penarikan komponen senyawa oleh pelarut maksimal, dimana parameter yang digunakan adalah sampai larutan metanol yang dihasilkan hampir bening atau warna larutan konstan, sehingga didapatkan ekstrak metanol daun bandotan. Ekstrak metanol daun bandotan disaring sehingga diperoleh ekstrak metanol bersih (tidak tercampur residu / pengotor), pelarut ekstrak diuapkan dengan menggunakan rotary evaporator dengan tekanan rendah sehingga proses penguapan cairan penyari menjadi cepat 
hingga didapatkan ekstrak kental. Setelah itu ekstrak diuapkan kembali di water bath untuk mendapatkan ekstrak kasar daun bandotan.

Fraksi yang akan dibuat adalah fraksi kloroform. Ekstrak metanol daun bandotan ditimbang sebanyak $10 \mathrm{~g}$ kemudian dilarutkan dengan air sebanyak $100 \mathrm{~mL}$. Campuran air dan ekstrak dimasukkan ke dalam corong pisah, kemudian disiapkan pelarut kloroform sebanyak $100 \mathrm{~mL}$, dimasukkan tiap 25 $\mathrm{mL}$ kloroform ke dalam corong pisah. Setelah beberapa menit akan terbentuk 2 lapisan. Lapisan bawah (lapisan kloroform) ditampung dan diuapkan. Lapisan air dilanjutkkan ke fraksinasi selanjutnya dengan penambahan $25 \mathrm{~mL}$ kloroform (diulang hingga $100 \mathrm{~mL}$ kloroform). Hasil fraksinasi dikeringkan/diuapkan sehingga diperoleh fraksi kloroform kering.

\section{Penentuan Profil Eluen KLT}

Penentuan eluen dilakukan dengan cara melihat profil kromatografi (KLT) dari setiap perbandingan eluen yang digunakan terhadap ekstrak fraksi yang dielusi dengan eluen tersebut. Dalam penelitian ini digunakan pelarut $n-$ heksana : etil asetat dengan berbegai perbandingan. Dengan melihat profil kromatografi dari masing-masing eluan dapat ditentukan eluen yang dapat memberikan pemisahan terbaik bagi senyawa yang terkandung dalam sampel uji.

Penentuan eluen dilakukan dengan cara melihat profil kromatografi (KLT) dari ekstrak yang dielusi dengan berbagai perbandingan pelarut. Dari penelitian yang telah dilakukan, diketahui bahwa eluen yang dapat memisahkan komponen senyawa dengan baik dilihat dari profil kromatografi masing-masing perbandingan eluen adalah eluen $n$ heksana: etil asetat $(2: 1)$, dari hasil elusi dengan eluen tersebut diperoleh 8 spot senyawa yang berbeda nilai Rf-nya. Profil kromatogram dapat dilihat pada Gambar 1.

Setelah diperoleh eluen yang dapat memisahkan komponen senyawa dari sampel uji, kemudian dilanjutkan dengan fraksinasi secara kromatografi cair vakum. Dari hasil fraksinasi ini diketahui jumlah senyawa yang terkandung dalam isolat semakin sedikit, yang dapat dilihat dari jumlah noda hasil elusi. Jumlah senyawa yang terkandung dalam hasil fraksi dapat menjadi salah satu parameter diperoleh pemisahan yang baik. Profil kromatogram senyawa hasil isolasi dari fraksi kloroform daun bandotan dapat dilihat pada Gambar 2 .

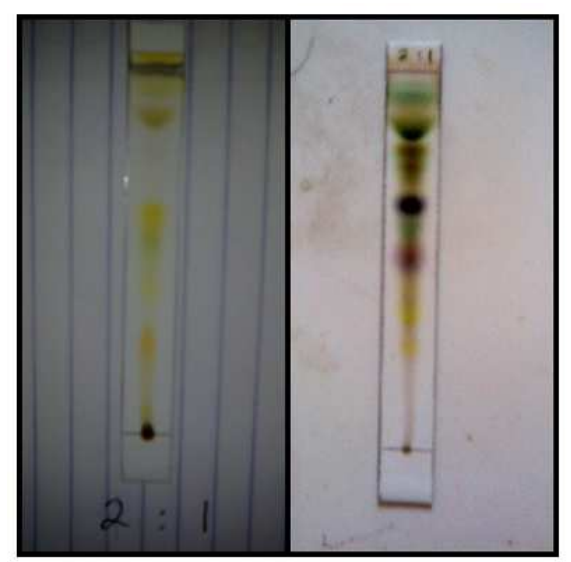

Eluen 2 : $1 \quad$ Pereaksi $\mathrm{H}_{2} \mathrm{SO}_{4} \quad 10 \%$

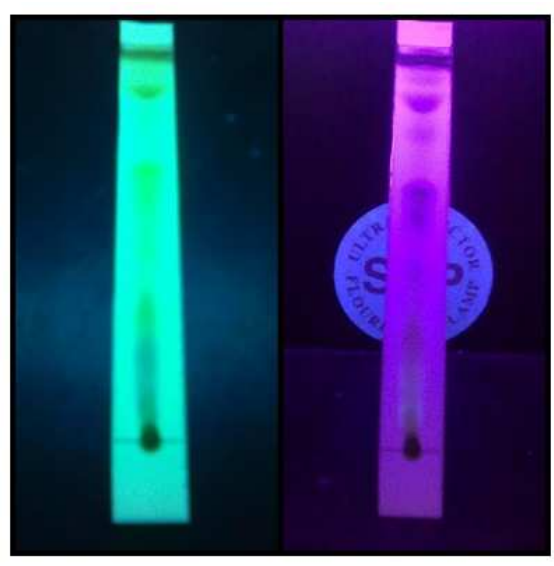

UV $254 \mathrm{~nm} \quad$ UV $366 \mathrm{~nm}$

Gambar 1. Profil kromatogram fraksi kloroform daun bandotan dengan eluen n-heksana : etil asetat $(2: 1)$ 
Tabel 1. Nilai Rf fraksi kloroform daun bandotan dengan eluen $n$-heksana: etil asetat (2:1)

\begin{tabular}{ccc}
\hline No. & Spot / Noda & Nilai Rf \\
\hline 1 & Spot 1 & 0,26 \\
2 & Spot 2 & 0,34 \\
3 & Spot 3 & 0,41 \\
4 & Spot 4 & 0,5 \\
5 & Spot 5 & 0,64 \\
6 & Spot 6 & 0,7 \\
7 & Spot 7 & 0,78 \\
8 & Spot 8 & 0,88 \\
\hline
\end{tabular}

Tabel 2. Nilai Rf senyawa hasil fraksinasi secara kolom cair vakum

No. vial fraksi $51-53$
Spot / Noda

Beberapa spot noda
Nilai Rf

0,59

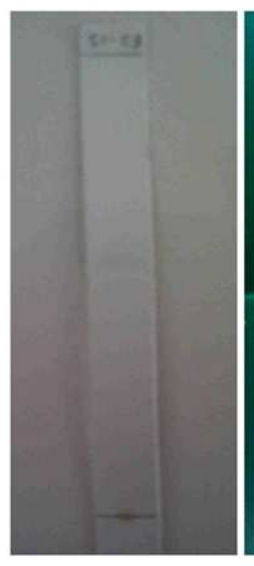

Elusi

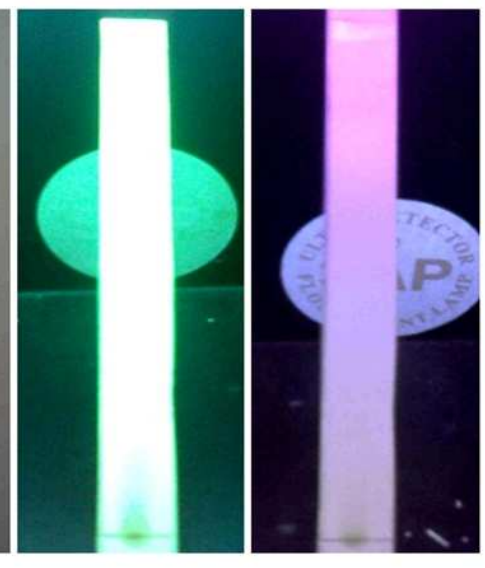

UV $254 \mathrm{~nm}$ UV $366 \mathrm{~nm}$

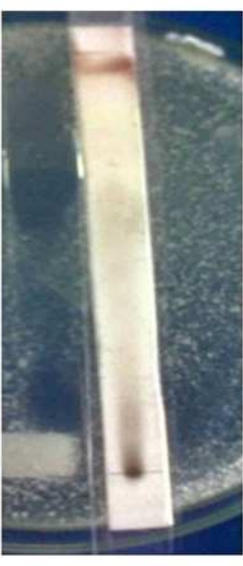

$\mathrm{H}_{2} \mathrm{SO}_{4} 10 \%$

Gambar 2. Profil kromatogram senyawa hasil fraksi kloroform daun bandotan

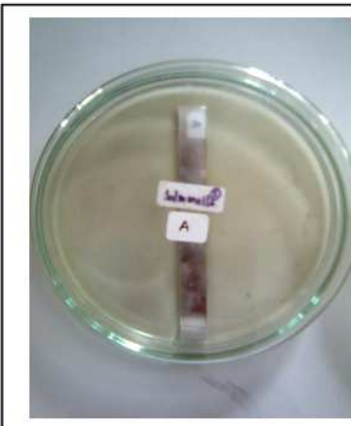

Salmonella thyposa

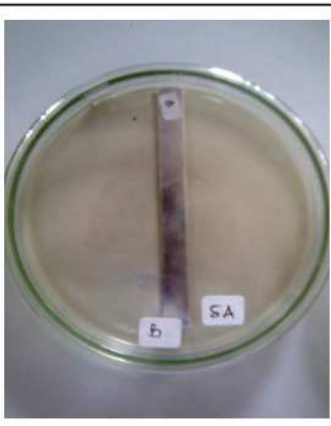

Staphylococcus aureus

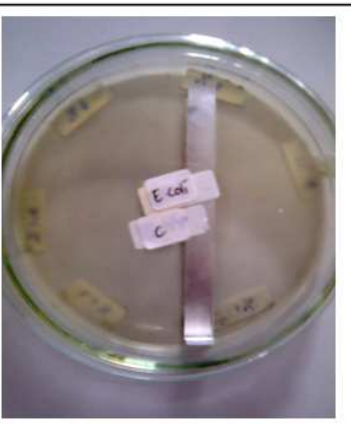

Eschericia coli

Gambar 3. Penanaman plat KLT pada medium GNA 


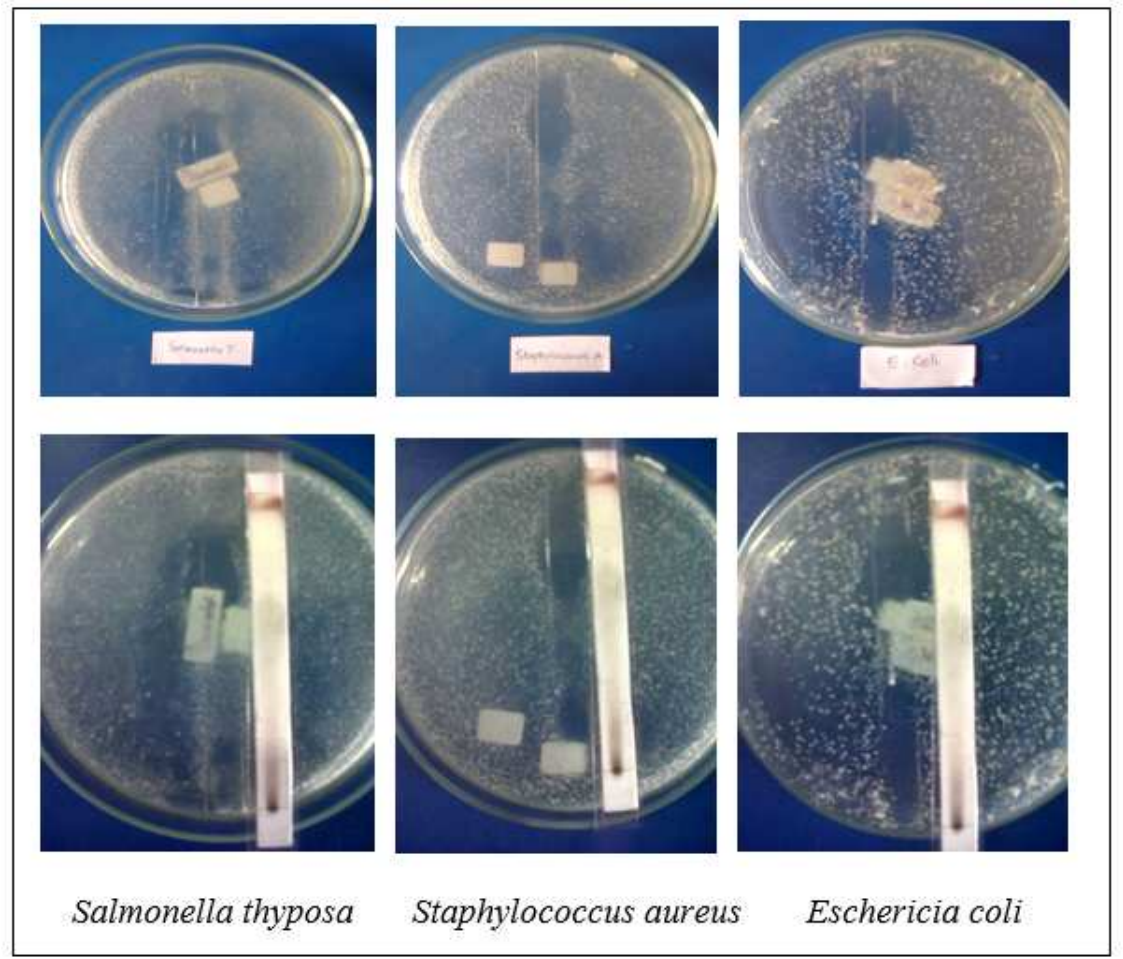

Gambar 4. Zona hambat pada medium GNA (aktivitas antibakteri)

\section{Uji Aktivitas Antibakteri secara KLT Bioautografi}

Senyawa antibakteri didefinisikan sebagai senyawa biologis atau kimia yang dapat menghambat pertumbuhan dan aktivitas bakteri. Dalam penelitian ini, pengujian antibakteri isolat dilakukan secara kualitatif dengan menggunakan metode KLT bioautografi. Bioautografi adalah suatu metode pendeteksian untuk menemukan suatu senyawa antimikroba (antibakteri) yang belum teridentifikasi, dengan cara melokalisir aktivitas antimikroba tersebut pada suatu kromatogram.

Fraksi yang akan diuji aktivitas antibakterinya terlebih dahulu dielusi dengan eluen yang sesuai untuk memisahkan komponen senyawa dalam fraksi dengan baik, dalam hal ini digunakan eluen $n$-heksana : etil asetat dengan perbandingan $3: 1$, dimana eluen ini dapat memisahkan komponen senyawa dalam fraksi dengan baik. Plat yang telah dielusi selanjutnya ditanam dalam medium Glukosa nutrien Agar (GNA) yang telah diinokulasikan masing-masing bakteri uji di dalamnya. Bakteri uji yang digunakan yaitu Salmonella thyposa, Staphylococcus aureus dan Eschericia coli. Penanaman plat dilakukan selama \pm 60 menit, selanjutnya plat diangkat dari dalam medium dan medium diinkubasi pada suhu $37^{\circ} \mathrm{C}$ selama 24 jam.

Berdasarkan hasil pengamatan yang dilakukan, fraksi kloroform daun bandotan dinyatakan memiliki aktivitas sebagai antibakteri, yang ditandai dengan terbentuknya zona hambat atau zona bunuh pada medium, yaitu dilihat dari terbentuknya zona bening di daerah noda pada plat yang telah ditanam dalam medium. Pengamatan dilakukan dengan cara mensejajarkan plat hasil elusi dengan zona bening yang terbentuk pada medium. Dengan demikian dapat diketahui kesesuaian antara noda pada plat dengan zona yang terbentuk.

Ciri khas dari prosedur bioautografi adalah didasarkan atas teknik difusi agar, dimana senyawa antimikroba (antibakteri) dipindahkan dari lapisan plat KLT ke medium agar 
yang telah diinokulasikan dengan merata bakteri uji di dalamnya. Dari hasil inkubasi pada suhu dan waktu tertentu akan terlihat zona hambatan disekeliling spot noda dari plat KLT yang telah ditempelkan pada media agar. Zona hambatan ditampakkan oleh aktivitas senyawa aktif yang terdapat di dalam bahan (isolat) terhadap pertumbuhan bakteri uji. Pengujian aktivitas antibakteri isolat daun bandotan dapat dilihat pada Gambar 3 dan Gambar 4.

\section{KESIMPULAN}

Berdasarkan hasil penelitian, diperoleh kesimpulan sebagai berikut:

a. Profil eluen KLT yang dapat memisahkan komponen senyawa pada sampel uji dengan baik adalah eluen n-heksana : etil asetat dengan perbandingan $2: 1$

b. Golongan senyawa hasil fraksinasi dari daun bandotan memiliki aktivitas sebagai antibakteri terhadap bakteri uji Salmonella thyposa, Staphylococcus aureus dan Eschericia coli yang dapat dilihat dari terbentuknya zona hambat pada daerah spot noda pada plat KLT yang ditanam di dalam medium Glukosa Nutrient Agar.

\section{SARAN}

Berdasarkan penelitian yang telah dilakukan, maka perlu beberapa hal untuk pengembangan ilmu pengetahuan. Adapun hal-hal yang perlu dilakukan yaitu :

a. Perlu dilakukan pengembangan eluen pada prosedur isolasi dengan menggunakan pelarut dan perbandingan yang lebih bervariasi

b. Perlu dilakukan pengujian lanjutan terhadap senyawa antibakteri dari isolat daun bandotan

\section{DAFTAR PUSTAKA}

1. Dalimartha, S. 2007. Atlas Tumbuhan Indonesia Jilid 2. Penerbit Puspa Swara; Jakarta
2. Darwis, D. 2000. Teknik Dasar Laboratorium Dalam Penelitian Senyawa Bahan Alam Hayati. Workshop Pengembangan SumberDayaManusia Dalam Bidang Kimia Organik Bahan Alam Hayati. FMIPA Universitas Andalas; Padang

3. Day, R.A., Underwood, A.L. 2002. Analisis Kimia Kuantitatif Edisi Keenam. Penerbit Erlangga; Jakarta

4. Djide, N. M. dan Sartini. 2008. Analisis Mikrobiologi Farmasi. Lab. Mikrobiologi Farmasi UNHAS

5. Efdi, M. 1999. Isolasi Alkaloid Dari Tumbuhan Ophiorrhiza cf. Kunstleri King. Makalah Seminar Hasil Program Pasca Sarjana. Universitas Andalas; Padang

6. Fadila, Z., 2010. Uji Aktivitas Antibakteri Ekstrak Etanol Daun Sirih (Pipper betle L.) Terhadap Propionibacterium acne dan Staphylococcus aureus Multiresisten. Skripsi Universitas Muhammadiyah; Surakarta

7. Goeswin, A. 2007. Teknologi Bahan Alam. ITB Press: Bandung

8. Irianto, K. 2006. Mikrobiologi Menguak Dunia Mikroorganisme. Bandung; Yrama Widya.

9. Morse, S. A., Janet, S. B., dan Geo., F. B. 2001. Mikrobiologi Kedokteran. Jakarta: Salemba Medika.

10. Okunade, A.L. 2002. Review Ageratum conyzoides L. (asteraceae). Fitoteria 73

11. Pamilih, H., 2009. Uji Sitotoksik Ektrak Etil Asetat Herba Bandotan (Ageratum conyziodes L.) Terhadap Sel Kanker Payudara (T47D) Dan Profil Kromatografi Lapis Tipis. Skripsi Fakultas Farmasi Universitas Muhammadiyah; Surakarta.

12. Rasid, M. 2011. Aktivitas Antibakteri Daun Bandotan (Ageratum conyzoides L.) Terhadap Beberapa Jenis Bakteri. Skripsi Fakultas Farmasi Universitas Mulawarman; Samarinda 
13. Ray, J.G., Bobbitt, J.M., Schwarting, A.E. 1991. Pengantar kromatografi Edisi Kedua. Penerbit ITB; Bandung.

14. Rohman, A. 2007, Kimia farmasi analisis. Pustaka Pelajar; Yogyakarta

15. Simbolon, O.M., 2011. Identifikasi Metabolit Sekunder dan Aktivitas Antioksidan Daun Bandotan (Ageratum conyzoides L.). Skripsi Fakultas Farmasi Universitas Mulawarman; Samarinda

16. Sudjadi. 1988. Metode Pemisahan. Kanisius; Yogyakarta

17. Todar, K. 2011. Salmonella dan Salmonellosis. University of Wisconsin-Madison Departemen of Bacteriology. Availabel from URL: (http://www.textbookofbacteriology.n et/ Salmonelladan Salmonellosis html) diakses pada 20 juni 2012
18. Yunita, T. 2010. Isolasi Senyawa Steroida dari Daun Tumbuhan Sisarah. Skripsi FMIPA Universitas Sumatera Utara; Medan

19. Zulkarnaen, N. 2010. Ekstraksi Antioksidan (Likopen) Dari Buah Tomat Dengan Menggunakan Solven Campuran n-Heksana, Aseton dan Etanol. Skripsi Jurusan Teknik Kimia Fakultas Teknik Universitas Diponegoro; Semarang 